На завершення зазначимо, що регламентація відповідальності за захоплення заручників за КК України та Республіки Польща має деякі спільні риси, проте багато в чому відрізняється, що обумовлюється притаманними кожній державі законотворчими традиціями та слідчосудовою практикою. Певні аспекти кримінально-правової характеристики цього посягання за польським законодавством (визначення об'єкта кримінально-правової охорони, перелік адресатів погроз, стимулювання позитивної посткримінальної поведінки тощо) становлять цікавість для України, а тому підлягають вивченню на предмет запозичення під час розробки нового вітчизняного КК.

\title{
Література:
}

1. Міжнародна конвенція про боротьбу із захопленням заручників : прийнята 17 грудня 1979 року. URL: https://zakon.rada.gov.ua/laws/show/ 995087 (дата звернення: 14.04.2021).

2. Kodeks karny Rzeczypospolitej Polskiej : Ustawa z dnia 6 czerwca 1997 roku. URL: http://isap.sejm.gov.pl/isap.nsf/DocDetails.xsp?id=WDU 19970880553 (дата звернення: 14.04.2021).

3. Кримінальний кодекс України : Закон України від 5 квітня 2001 року № 2341-III. URL: https://zakon.rada.gov.ua/laws/show/234114\#Text (дата звернення: 14.04.2021).

4. Кримінальний кодекс України : Закон України від 28 грудня 1960 року. URL: https://zakon.rada.gov.ua/laws/show/2001-05\#Text (дата звернення: 14.04.2021).

DOI https://doi.org/10.30525/978-9934-26-074-2-44

\section{REGARDING FINLAND'S EXPERIENCE IN COMBATING CORRUPTION}

\author{
Borovyk A. V. \\ Candidate of Juridical Sciences, Docent, \\ Professor at the Department of Criminal-Legal \\ and Administrative-Legal Disciplines \\ Academician Stepan Demianchuk International University \\ of Economics and Humanities \\ Rivne, Ukraine
}

Finland, as a member of the EU, is a party to all the main European Union legislation on combating organized crime and corruption. However, 
the implementation of European laws in the national legal system is carried out by this country fairly well. The main principle of this process is the organic combination of national legislation of Finland with the general European one with the least possible changes of first. For the Finnish legal system, laws aren't characterized by the use of the term «struggle» with the definition of a particular type of crime.) [1, p. 39-40]. The Finnish legislator laid down the principles of prevention and caution in the commission of crimes in each normative-legal act, which determine the specific sphere of activity, and not the type of crime. According to the provisions of the Criminal Code of Finland, for the commission of actions that may qualify as «corruption», there are of the sanctions from fines to imprisonment for up to four years depending on the degree of public danger of a crime [2, p. 12].

A genuine guarantee of protection of persons who assist the authorities in combating corruption is also facilitated for the low level of corruption in public authorities and the administration of Finland [3, p. 45]. Concerning the implementation of the requirements of the Convention against Corruption in 2003, the United Nations Review Panel on the Prevention of Corruption [4] made observations on Finland that could be considered in terms of further development of the anti-corruption system, including those related to the Institute of exemption from liability (punishment) of persons for corruption crimes. In particular, for Finland is recommended to:

- to consider the possibility of exemption from punishment of persons who committed acts of corruption in the event of their voluntary and active cooperation with law-enforcement bodies;

- to consider extending the scope of the domestic law on mitigating punishments of persons who committed corruptive crimes in the event that they voluntarily and substantially assist law enforcement authorities in investigating crimes committed by other persons who are in one court cause and in a gathering evidence.

Importance has ethics, respect for work and disrespect for tricks, dishonesty, and unjustified agility in the enriched ones in Finland. Finns believe that taking a bribe means losing self-esteem even if nobody knows about it. There are municipalities with a population of only 200 , but they have self-government. The principle of the election of local administrations really works here (corruption often flourishes at the local level) [5].

Thus, the experience of Finland confirms that in this country, however, as in other developed democracies, the main factor in counteracting corruption is, first of all, honest power. It is also a system of interaction between government, civil society, traditions and values of the nation. Honest power does not depend on personality, it is laid in the culture, mentality of the people. Actually, the Ukrainian state is trying to capture such an approach for its citizens. The conducted studies confirmed that this is the most effective and most powerful way. 


\title{
References:
}

1. Vidpovidalnist za koruptsiini diiannia, pravovi zasady vidshkoduvannia zbytkiv, zavdanykh vnaslidok yikh vchynennia: navch.-metod. materialy / Yu. V. Baskakova, V. M. Havryliuk, P. V. Kachanova, H. O. Usatyi ; uporiad. O. V. Zhur. Kyiv: NADU, 2013. P. 39-40.

2. Antykoruptsiine zakonodavstvo: mizhnarodni standarty ta yikh zaprovadzhennia $\mathrm{v}$ Ukraini : metod. posib. / uklad.: V. I. Hryhoriev, M. A. Mykytiuk, H. O. Honcharuk. Kyiv, 2013. P. 12.

3. Bocharnykov Y. V. Zarubezhnyi opyt protyvodeistvyia korruptsyi. Analytycheskyi vestnyk Analytycheskoho upravlenyia Apparata Soveta Federatsyi Federalnoho Sobranyia Rossyiskoi Federatsyi. 2007. № 6 (351). P. 45.

4. Reziume stranovykh dokladov (zapyska sekretaryata OON), podhotovlennoe v ramkakh Konferentsyy hosudarstv - uchastnykov Konventsyy Orhanyzatsyy Ob'yedynennykh Natsyi protyv korruptsyy, Hruppoi po obzoru khoda osushchestvlenyia Konventsyy Orhanyzatsyy Ob'yedynennykh Natsyi protyv korruptsyy 7 yiunia 2011 hoda (h. Vena) [Elektronnyi resurs]. Rezhym dostupa: http://sartraccc.ru/Pub_inter/unvscorr.files/ V1183527r.pdf

5. Nevmerzhytskyi Ye. Problemy retseptsii antykoruptsiinykh mekhanizmiv rozvynenykh krain v ukrainsku praktyku [Elektronnyi resurs]. Viche. 2011. № 19. Rezhym dostupu : http://www.viche.info/journal/2731/

DOI https://doi.org/10.30525/978-9934-26-074-2-45

\section{ВРАХУВАННЯ ОКРЕМИХ ПРИНЦИПІВ КРИМІНАЛІЗАЦІЇ У ЧЕРГОВИХ ЗМІНАХ ДО СТАТТІ 209 КРИМІНАЛЬНОГО КОДЕКСУ УКРАЇНИ}

\author{
Гладковський М. О. \\ аспірант кафедри кримінального права \\ Київького національного університету імені Тараса Шевченка \\ м. Київ, Україна
}

3 моменту прийняття Кримінального кодексу України (далі - КК) ст. 209 «Легалізація (відмивання) майна, одержаного злочинним шляхом» можна віднести до переліку тих статей, що зазнали значної кількості змін. Останні зміни у цій статті відбулися у зв'язку з прийняттям Закону України від 6 грудня 2019 року № 361-IX «Про запобігання та протидію легалізації (відмиванню) доходів, одержаних злочинним шляхом, фінансуванню тероризму та фінансуванню розповсюдження 